\title{
Halorubrum kocurii sp. nov., an archaeon isolated from a saline lake
}

\author{
Correspondence \\ M. C. Gutiérrez \\ mcg@us.es
}

\author{
M. C. Gutiérrez, ${ }^{1}$ A. M. Castillo, ${ }^{1}$ E. Pagaling, ${ }^{2}$ S. Heaphy, ${ }^{2}$ M. Kamekura, ${ }^{3}$ \\ Y. Xue, ${ }^{4}$ Y. Ma, ${ }^{4}$ D. A. Cowan, ${ }^{5}$ B. E. Jones, ${ }^{6}$ W. D. Grant ${ }^{2}$ and A. Ventosa ${ }^{1}$
}
${ }^{1}$ Department of Microbiology and Parasitology, Faculty of Pharmacy, University of Sevilla, 41012 Sevilla, Spain
${ }^{2}$ Department of Infection, Immunity and Inflammation, University of Leicester, Leicester LE1 9HN, UK
${ }^{3}$ Halophiles Research Institute, 677-1 Shimizu, Noda-shi, Chiba-ken 278-0043, Japan
${ }^{4}$ State Key Laboratory of Microbial Resources, Institute of Microbiology, Chinese Academy of Sciences, 100101 Beijing, PR China
${ }^{5}$ Institute for Microbial Biotechnology and Metagenomics, University of the Western Cape, Bellville 7535, Cape Town, South Africa
${ }^{6}$ Genencor International BV, Archimedesweg 30, 2333 CN Leiden, The Netherlands

\begin{abstract}
A Gram-negative, non-motile, neutrophilic, rod-shaped, extremely halophilic archaeon, designated strain $B G-1^{\top}$, was isolated from a salt lake, Lake Bagaejinnor, in Inner Mongolia, China. Strain $\mathrm{BG}-1^{\top}$ was able to grow at $25-55^{\circ} \mathrm{C}$, required at least $2.5 \mathrm{M} \mathrm{NaCl}$ for growth (with an optimum at 3.4 $\mathrm{M} \mathrm{NaCl}$ ) and grew at $\mathrm{pH}$ 6.0-9.0 (with an optimum at $\mathrm{pH}$ 7.5). Hypotonic treatment with less than $2.0 \mathrm{M} \mathrm{NaCl}$ caused cell lysis. Phylogenetic analysis of the almost-complete $16 \mathrm{~S}$ rRNA gene sequence positioned the isolate within the genus Halorubrum in the family Halobacteriaceae. Strain BG-1 ${ }^{\top}$ was most closely related to Halorubrum aidingense 31 -hong ${ }^{\top}$ (98.8\% sequence similarity), Halorubrum saccharovorum NCIMB $2081^{\top}$ (98.6\%), Halorubrum lacusprofundi ACAM $34^{\top}(98.6 \%)$ and Halorubrum lipolyticum 9-3 ${ }^{\top}$ (98.4\%). However, values for DNA-DNA hybridization between strain $B G-1^{\top}$ and the most closely related members of the genus Halorubrum were below $40 \%$. Analysis of the polar lipids of strain $B G-1^{\top}$ revealed the presence of mannosyl-2-sulfate-(1-4)-glycosyl-archaeol, the main glycolipid found in neutrophilic species of the genus Halorubrum. The $\mathrm{G}+\mathrm{C}$ content of the genomic DNA was $69.4 \mathrm{~mol} \%\left(T_{\mathrm{m}}\right)$. Comparison of the phenotypic characteristics of the strain with those of Halorubrum species supported the conclusion that $B G-1^{\top}$ represents a novel species within this genus, for which the name Halorubrum kocurii sp. nov. is proposed. The type strain is BG-1 ${ }^{\top}$ (=CECT $7322^{\top}$ $=$ CGMCC $1.7018^{\top}=\mathrm{JCM} 14978^{\top}$ ).
\end{abstract}

Aerobic, extremely halophilic archaea typically comprise red-pigmented micro-organisms that belong to the family Halobacteriaceae (Grant et al., 2001). They are the most halophilic organisms known and are predominant in hypersaline environments in which the salt concentration exceeds $250 \mathrm{~g} \mathrm{l}^{-1}$ (Rodriguez-Valera et al., 1981; Ventosa, 2006). Cell densities may be sufficiently high in hypersaline brines to impart a red colour. Recent studies based on phylogenetic analyses of $16 \mathrm{~S}$ rRNA genes have revealed a

The GenBank/EMBL/DDBJ accession number for the 16S rRNA gene sequence of strain $B G-1^{\top}$ is $A M 900832$.

A thin-layer chromatogram of polar lipids extracted from strain $B G-1^{\top}$ and some other haloarchaea is available as supplementary material with the online version of this paper. very high taxonomic diversity at both the genus and species level within the family Halobacteriaceae (Grant et al., 2001; Ventosa, 2006). At the time of writing, the family Halobacteriaceae includes 26 genera and 85 species (Oren et al., 2007).

The genus Halorubrum was originally proposed by McGenity \& Grant (1995) to accommodate several species previously included in the genus Halobacterium. Currently, the genus Halorubrum comprises 19 species with validly published names: Halorubrum saccharovorum (Tomlinson \& Hochstein, 1976), Hrr. trapanicum (Petter, 1931), Hrr. sodomense (Oren, 1983), Hrr. lacusprofundi (Franzmann et al., 1988), Hrr. coriense (Oren \& Ventosa, 1996), Hrr. distributum (Oren \& Ventosa, 1996), Hrr. vacuolatum 
(Kamekura et al., 1997), Hrr. tebenquichense (Lizama et al., 2002), Hrr. tibetense (Fan et al., 2004), Hrr. terrestre (Ventosa et al., 2004), Hrr. xinjiangense (Feng et al., 2004), Hrr. alkaliphilum (Feng et al., 2005), Hrr. ezzemoulense (Kharroub et al., 2006), Hrr. orientale (Castillo et al., 2006), Hrr. lipolyticum (Cui et al., 2006), Hrr. aidingense (Cui et al., 2006), Hrr. arcis (Xu et al., 2007), Hrr. litoreum (Cui et al., 2007) and Hrr. ejinorense (Castillo et al., 2007). The aim of this study was to describe a novel non-alkaliphilic halophilic archaeon isolated from Lake Bagaejinnor in Inner Mongolia, China. We propose that it represents a novel species of the genus Halorubrum. This archaeon is the host for a halovirus, designated $\mathrm{BJ} 1$, the complete genomic sequence of which has been reported recently (Pagaling et al., 2007).

Strain $\mathrm{BG}-1^{\mathrm{T}}$ was isolated from a sediment and water sample from a saline lake, Lake Bagaejinnor $\left(45^{\circ} 09^{\prime} \mathrm{N} 116^{\circ}\right.$ $36^{\prime} \mathrm{E}$ ). At the time of sampling (September 2003), the water of this lake had a temperature of $20.5^{\circ} \mathrm{C}$, a pH of 8.5 and a conductivity of $146.7 \mathrm{mS} \mathrm{cm}{ }^{-1}$. Approximately $0.5 \mathrm{~g}$ of the sample was dissolved in the medium and serially diluted; $100 \mu \mathrm{l}$ of each dilution was plated on plates with solid isolation medium containing the following $\left(1^{-1}\right)$ : yeast extract, $10 \mathrm{~g}$; Casamino acids, $7.5 \mathrm{~g}$; NaCl, $130 \mathrm{~g}$; $\mathrm{MgCl}_{2} .7 \mathrm{H}_{2} \mathrm{O}, 71.16 \mathrm{~g} ; \mathrm{Na}_{2} \mathrm{SO}_{4}, 45.6 \mathrm{~g}$; trisodium citrate, 3 g; KCl, 2.48 g; $\mathrm{Na}_{2} \mathrm{~B}_{4} \mathrm{O}_{7}, 1.62$ g; $\mathrm{NaBr}, 0.84$ g; $\mathrm{NaHCO}_{3}$, $0.62 \mathrm{~g} ; \mathrm{Na}_{2} \mathrm{CO}_{3}, 0.36 \mathrm{~g}$; the $\mathrm{pH}$ was adjusted to 8.0. Strain BG- $1^{\mathrm{T}}$ was isolated and a pure culture was obtained after several transfers on the same medium.

Strain $\mathrm{BG}-1^{\mathrm{T}}$ grew at temperatures in the range $25-55{ }^{\circ} \mathrm{C}$ (optimally at $37^{\circ} \mathrm{C}$ ) and at $\mathrm{pH} 6.0-9.0$ (optimally at $\mathrm{pH}$ 7.5). Routine cultivation was conducted at $37^{\circ} \mathrm{C}$ and $\mathrm{pH}$ 7.5. $\mathrm{NaCl}$ and magnesium requirements for growth were tested in media with $1.0-5.2 \mathrm{M} \mathrm{NaCl}$ or $0-0.5 \mathrm{M}$ $\mathrm{MgCl}_{2}$. Strain BG-1 ${ }^{\mathrm{T}}$ was capable of growth over a wide range of $\mathrm{NaCl}$ concentrations, ranging from $2.5 \mathrm{M}$ (approx. $15 \%$ ) to $5.0 \mathrm{M}$ (approx. $30 \%$ ). It grew optimally in the presence of $3.4 \mathrm{M}(20 \%) \mathrm{NaCl}$, as has been shown for most extremely halophilic archaea (Grant et al., 2001). $\mathrm{MgCl}_{2}$ was not required for growth.

Phenotypic characterization was carried out in accordance with the recommended minimal standards for the description of novel taxa in the order Halobacteriales (Oren et al., 1997). Anaerobic growth was tested in the presence of $5 \%$ nitrate and $3 \% \mathrm{~L}$-arginine in filled, stoppered tubes (Oren et al., 1997). The formation of acid from different sugars was tested in medium with $0.05 \%(\mathrm{w} / \mathrm{v})$ yeast extract and supplemented with $1 \%(\mathrm{w} / \mathrm{v})$ of the sugar tested (sterilized separately). Strain BG-1 ${ }^{\mathrm{T}}$ was oxidase- and catalase-positive. The following tests produced negative results: methyl red, Voges-Proskauer, indole production from tryptone and Simmons' citrate. The strain was positive for nitrate reduction. Casein, aesculin, DNA and starch were not hydrolysed. The urease test was positive. Other phenotypic characteristics of strain $\mathrm{BG}-1^{\mathrm{T}}$ are summarized in Table 1 and the species description.
Table 1. Differentiation of strain BG-1 ${ }^{\top}$ from closely related species of the genus Halorubrum

Taxa: 1, strain BG-1 ${ }^{\mathrm{T}}$; 2, Hrr. saccharovorum NCIMB $2081^{\mathrm{T}}$; 3, Hrr. aidingense JCM $13560^{\mathrm{T}}$; 4, Hrr. lacusprofundi ACAM $34^{\mathrm{T}}$; 5, Hrr. lipolyticum JCM $13559^{\mathrm{T}}$. Data are from this study, McGenity \& Grant (2001) and Cui et al. (2006). +, Positive; -, negative; w, weak; ND, no data available.

\begin{tabular}{|lccccc|}
\hline Characteristic & $\mathbf{1}$ & $\mathbf{2}$ & $\mathbf{3}$ & $\mathbf{4}$ & $\mathbf{5}$ \\
\hline Motility & - & + & + & + & + \\
$\mathrm{Mg}^{2+}$ required & - & + & - & + & + \\
$\mathrm{H}_{2}$ S formation & - & - & + & - & + \\
Nitrate reduction & + & - & + & $\mathrm{W}$ & + \\
Indole formation & - & - & + & - & - \\
Starch hydrolysis & - & - & - & - & + \\
Urease & + & - & $\mathrm{ND}$ & - & $\mathrm{ND}$ \\
Gelatin liquefaction & - & - & - & - & + \\
Utilization of: & & & & & \\
$\quad$ D-Glucose & - & + & + & + & + \\
$\quad$ D-Galactose & - & - & + & + & + \\
D-Mannose & - & + & + & + & + \\
D-Ribose & - & - & - & + & - \\
D-Xylose & + & + & - & - & - \\
Acetate & - & + & + & + & - \\
DNA G+C content & 69.4 & 71.2 & 64.2 & 65.3 & 65.9 \\
$\quad$ (mol\%) & & & & & \\
\hline
\end{tabular}

To determine the utilization of different organic substrates as carbon and energy sources or as carbon, nitrogen and energy sources, a medium containing yeast extract at $0.05 \%(\mathrm{w} / \mathrm{v})$, supplemented with $1 \%(\mathrm{w} / \mathrm{v})$ of the tested substrate, was used (Torreblanca et al., 1986). Susceptibility to antibiotics was determined on agar plates by using antibiotic discs with the following amounts: ampicillin $(10 \mu \mathrm{g})$, bacitracin $(10 \mathrm{U})$, chloramphenicol $(30 \mu \mathrm{g})$, erythromycin $(15 \mu \mathrm{g})$; gentamicin $(10 \mu \mathrm{g})$, nalidixic acid $(30 \mu \mathrm{g})$, neomycin $(10 \mu \mathrm{g})$, novobiocin $(30 \mu \mathrm{g})$, penicillin $\mathrm{G}(10 \mathrm{U})$, rifampicin $(30 \mu \mathrm{g})$, streptomycin $(10 \mu \mathrm{g})$ and tetracycline $(30 \mu \mathrm{g})$. The results for the utilization of different substrates and for antibiotic susceptibility are included in the species description.

Cell morphology and motility were examined using an Olympus BX41 microscope equipped with phase-contrast optics. Cells were non-motile and rod-shaped (Fig. 1). Colony morphology was observed on solid medium under optimal growth conditions after incubation at $37^{\circ} \mathrm{C}$ for 5 days. Colonies of strain $\mathrm{BG}-1^{\mathrm{T}}$ that formed on agar plates were circular, smooth, entire, opaque, red-pigmented and $0.5-1.5 \mathrm{~mm}$ in diameter.

Polar lipids were extracted with chloroform/methanol as described previously (Kamekura, 1993). TLC was done using Merck HPTLC silica gel 60 plates (art. 5641) in the solvent system, chloroform/methanol/acetic acid/water $(85: 22.5: 10: 4$, by vol.). Glycolipids were detected as purple spots by spraying with $0.5 \% \quad \alpha$-naphthol in 


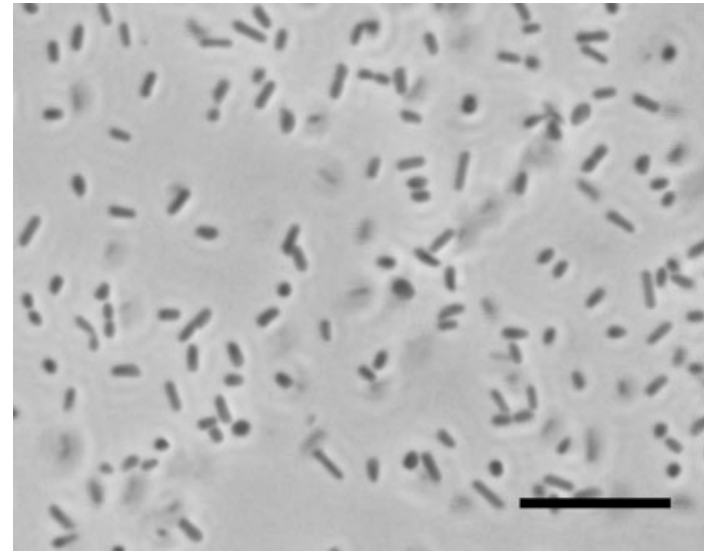

Fig. 1. Phase-contrast micrograph of cells of strain $B G-1^{\top}$ grown in liquid medium under optimal conditions. Bar, $15 \mu \mathrm{m}$.

methanol/water $(1: 1)$ and then with sulfuric acid/ethanol $(1: 1)$, followed by heating at $160{ }^{\circ} \mathrm{C}$. The polar lipids of strain $\mathrm{BG}-1^{\mathrm{T}}$ are $\mathrm{C}_{20} \mathrm{C}_{20}$ derivatives of phosphatidylglycerol, phosphatidylglycerol phosphate methyl ester and a sulfated diglycosyl archaeol [mannosyl-2-sulfate-(1-4)-glycosyl-archaeol] (see Supplementary Fig. S1, available in IJSEM Online). This polar lipid profile has been shown to be a distinctive feature of non-alkaliphilic species of the genus Halorubrum (McGenity \& Grant, 2001).

Chromosomal DNA of strain BG-1 ${ }^{\mathrm{T}}$ was isolated and purified according to the method described by Marmur (1961). The G+C content of genomic DNA was determined from the mid-point $\left(T_{\mathrm{m}}\right)$ of the thermal denaturation profile (Marmur \& Doty, 1962), using the equation of Owen \& Hill (1979). The DNA G + C content of strain $\mathrm{BG}-\mathrm{1}^{\mathrm{T}}$ was $69.4 \mathrm{~mol} \%$. The $16 \mathrm{~S}$ rRNA gene of strain $\mathrm{BG}-\mathrm{1}^{\mathrm{T}}$ was amplified using a PCR with three universal primer sets, as described previously (Lopez-Garcia et al., 2001; Arahal et al., 1996) and the almost-complete nucleotide sequence (1369 bp) was determined. The ARB software package (Ludwig et al., 2004) was used for $16 S$ rRNA gene sequence analysis. Basefrequency filters were applied in the sequence-comparison analysis and the effects on the results were evaluated. In the phylogenetic tree constructed with the maximum-parsimony method (Saitou \& Nei, 1987), strain BG-1 ${ }^{\mathrm{T}}$ clustered with the type strains of species of the genus Halorubrum (Fig. 2). The 16S rRNA gene sequence similarities between strain $\mathrm{BG}-1^{\mathrm{T}}$ and the most closely related Halorubrum type strains, Hrr. aidingense 31-hong ${ }^{\mathrm{T}}$, Hrr. saccharovorum NCIMB $2081^{\mathrm{T}}$, Hrr. lacusprofundi ACAM $34^{\mathrm{T}}$ and Hrr. lipolyticum 9-3 ${ }^{\mathrm{T}}$, were 98.8, 98.6, 98.6 and $98.4 \%$, respectively. Similar tree topologies were obtained when other treeing methods (neighbour joining and maximum likelihood) were used.

To verify the species status of strain $\mathrm{BG}-\mathrm{1}^{\mathrm{T}}$, DNA-DNA hybridization studies were carried out with the type strains of the most closely related species of Halorubrum. These studies were performed using the competition procedure of the membrane method (Johnson, 1994) as described in detail by Ventosa et al. (2004). The levels of DNA-DNA relatedness for strain $\mathrm{BG}-1^{\mathrm{T}}$ with respect to Hrr. aidingense JCM $13560^{\mathrm{T}}$, Hrr. saccharovorum NCIMB $2081^{\mathrm{T}}$, Hrr. lipolyticum JCM $13559^{\mathrm{T}}$ and Hrr. lacusprofundi ACAM $34^{\mathrm{T}}$ were $27,28,36$ and $39 \%$, respectively. These data indicate that strain BG-1 ${ }^{\mathrm{T}}$ represents a novel species of the genus Halorubrum, having DNA-DNA hybridization values $<70 \%$ with respect to members of recognized species (Stackebrandt \& Goebel, 1994). In addition, several phenotypic differences were observed between strain BG- $1^{\mathrm{T}}$ and the most closely related Halorubrum species, including those concerning motility, urease production and the utilization of glucose and other sugars (Table 1).

Therefore, on the basis of the data from this polyphasic study, strain BG- $1^{\mathrm{T}}$ represents a novel species of the genus Halorubrum, for which the name Halorubrum kocurii sp. nov. is proposed.

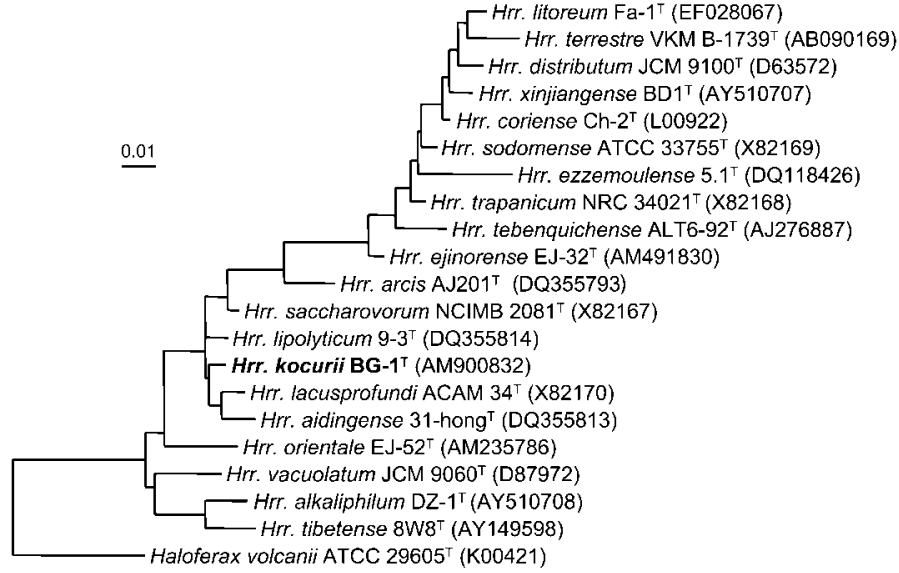

Fig. 2. Maximum-parsimony phylogenetic tree, based on 16S rRNA gene sequence comparison, showing the position of strain $B G-1^{\top}$ among the species of the genus Halorubrum. EMBL accession numbers are given in parentheses. Bar, $1 \%$ sequence divergence. 


\section{Description of Halorubrum kocurii sp. nov.}

Halorubrum kocurii (ko.cu'ri.i. N.L. gen. masc. n. kocurii of Kocur, named for the Czech microbiologist M. Kocur, a pioneer in the study of halophilic archaea and bacteria).

Cells are non-motile, rod-shaped $(2-5 \times 0.9-1.1 \mu \mathrm{m})$ (Fig. 1) and Gram-negative. Colonies are circular, smooth, entire, opaque, red-pigmented and $0.5-1.5 \mathrm{~mm}$ in diameter after 5 days at $37{ }^{\circ} \mathrm{C}$ on plates containing $20 \%(w / v)$ total salts. Cells are extremely halophilic and lyse in water. At least $2.5 \mathrm{M} \mathrm{NaCl}$ is required for growth, the optimum concentration being $3.4 \mathrm{M} \mathrm{NaCl} . \mathrm{MgCl}_{2}$ is not required for growth. The $\mathrm{pH}$ and temperature ranges for growth are $\mathrm{pH}$ 6.0-9.0 (optimum, $\mathrm{pH} 7.5$ ) and $25-55{ }^{\circ} \mathrm{C}$ (optimum, $37^{\circ} \mathrm{C}$ ). Chemo-organotrophic, aerobic and oxidase- and catalase-positive. Indole is not produced from tryptophan. Methyl red, Voges-Proskauer and Simmons' citrate tests produce negative results. Acid is not produced from lactose, glycerol, D-glucose, sucrose, D-fructose, D-arabinose, maltose, D-galactose, trehalose or D-mannose. Does not grow anaerobically in the presence of nitrate or Larginine. Starch, gelatin, DNA, aesculin and casein are not hydrolysed. Urea is hydrolysed. Does not produce arginine dihydrolase, lysine decarboxylase or ornithine decarboxylase. Nitrate is reduced to nitrite; gas is not produced from nitrite. Utilizes D-xylose. No growth is observed on Dglucose, D-fructose, glycerol, maltose, trehalose, starch, propionate, fumarate, acetate, L-lysine, D-mannitol, Dsorbitol, lactose, D-arabinose, D-galactose, D-mannose, raffinose, D-ribose, malate, succinate, glutamate, isoleucine, L-serine or glycine. Sensitive to bacitracin, novobiocin and rifampicin. Resistant to ampicillin, chloramphenicol, erythromycin, gentamicin, nalidixic acid, neomycin, penicillin G, streptomycin and tetracycline. The polar lipids are phosphatidylglycerol, phosphatidylglycerol phosphate methyl ester and the glycolipid mannosyl-2-sulfate-(1-4)glycosyl-archaeol. The DNA G $+\mathrm{C}$ content is $69.4 \mathrm{~mol} \%$ $\left(T_{\mathrm{m}}\right)$.

The type strain, BG-1 ${ }^{\mathrm{T}}\left(=\right.$ CECT $7322^{\mathrm{T}}=$ CGMCC $1.7018^{\mathrm{T}}$ $=\mathrm{JCM} 14978^{\mathrm{T}}$ ), was isolated from saline Lake Bagaejinnor in Inner Mongolia, China.

\section{Acknowledgements}

This study was supported by grants from the Quality of Life and Management of Living Resources Programme of the European Commission (Project 'Multigenome Access Technology for Industrial Catalysts', QLK3-CT-2002-01972), the Spanish Ministerio de Educación y Ciencia (BIO2006-06927) and the Junta de Andalucía (P06-CVI-01829).

\section{References}

Arahal, D. R., Dewhirst, F. E., Paster, B. J., Volcani, B. E. \& Ventosa, A. (1996). Phylogenetic analyses of some extremely halophilic archaea isolated from Dead Sea water, determined on the basis of their $16 \mathrm{~S}$ rRNA sequences. Appl Environ Microbiol 62, 3779-3786.
Castillo, A. M., Gutiérrez, M. C., Kamekura, M., Xue, Y., Ma, Y., Cowan, D. A., Jones, B. E., Grant, W. D. \& Ventosa, A. (2006). Halorubrum orientale sp. nov., a halophilic archaeon isolated from Lake Ejinor, Inner Mongolia, China. Int J Syst Evol Microbiol 56, 2559-2563.

Castillo, A. M., Gutiérrez, M. C., Kamekura, M., Xue, Y., Ma, Y., Cowan, D. A., Jones, B. E., Grant, W. D. \& Ventosa, A. (2007). Halorubrum ejinorense sp. nov., a isolated from Lake Ejinor, Inner Mongolia, China. Int J Syst Evol Microbiol 57, 2538-2542.

Cui, H.-L., Tohty, D., Zhou, P.-J. \& Liu, S.-J. (2006). Halorubrum lipolyticum sp. nov. and Halorubrum aidingense sp. nov., isolated from two salt lakes in Xin-Jiang, China. Int J Syst Evol Microbiol 56, 1631-1634.

Cui, H.-L., Lin, Z.-Y., Dong, Y., Zhou, P.-J. \& Liu, S.-J. (2007). Halorubrum litoreum sp. nov., an extremely halophilic archaeon from a solar saltern. Int J Syst Evol Microbiol 57, 2204-2206.

Fan, H., Xue, Y., Ma, Y., Ventosa, A. \& Grant, W. D. (2004). Halorubrum tibetense sp. nov., a novel haloalkaliphilic archaeon from Lake Zabuye in Tibet, China. Int J Syst Evol Microbiol 54, 1213-1216.

Feng, J., Zhou, P. \& Liu, S. (2004). Halorubrum xinjiangense sp. nov., a novel halophile isolated from saline lakes in China. Int J Syst Evol Microbiol 54, 1789-1791.

Feng, J., Zhou, P., Zhou, Y., Liu, S. \& Warren-Rhodes, K. (2005). Halorubrum alkaliphilum sp. nov., a novel haloalkaliphile isolated from a soda lake in Xinjiang, China. Int J Syst Evol Microbiol 55, 149-152.

Franzmann, P. D., Stackebrandt, E., Sanderson, K., Volkman, J. K., Cameron, D. E., Stevenson, P. L., McMeekin, T. A. \& Burton, H. R. (1988). Halobacterium lacusprofundi sp. nov., a halophilic bacterium isolated from Deep Lake, Antarctica. Syst Appl Microbiol 11, 20-27.

Grant, W. D., Kamekura, M., McGenity, T. J. \& Ventosa, A. (2001). Order I. Halobacteriales Grant and Larsen 1989b, 495 ${ }^{\mathrm{VP}}$ (effective publication: Grant and Larsen 1989a, 2216). In Bergey's Manual of Systematic Bacteriology, 2nd edn, vol. 1, pp. 294-334. Edited by D. R. Boone, R. W. Castenholz \& G. M. Garrity. New York: Springer.

Johnson, J. L. (1994). Similarity analysis of DNAs. In Methods for General and Molecular Bacteriology, pp. 655-681. Edited by P. Gerhardt, R. G. E. Murray, W. A. Wood \& N. R. Krieg. Washington, DC: American Society for Microbiology.

Kamekura, M. (1993). Lipids of extreme halophiles. In The Biology of Halophilic Bacteria, pp. 135-161. Edited by R. H. Vreeland \& L. I. Hochstein. Boca Raton, FL: CRC Press.

Kamekura, M., Dyall-Smith, M. L., Upasani, V., Ventosa, A. \& Kates, M. (1997). Diversity of alkaliphilic halobacteria: proposals for transfer of Natronobacterium vacuolatum, Natronobacterium magadii, and Natronobacterium pharaonis to Halorubrum, Natrialba and Natronomonas gen. nov., respectively, as Halorubrum vacuolatum comb. nov., Natrialba magadii comb. nov., and Natronomonas pharaonis comb. nov., respectively. Int J Syst Bacteriol 49, 131-136.

Kharroub, K., Quesada, E., Ferrer, R., Fuentes, S., Aguilera, M., Boulahrouf, A., Ramos-Cormenzana, A. \& Monteoliva-Sánchez, M. (2006). Halorubrum ezzemoulense sp. nov., a halophilic archaeon isolated from Ezzemoul sabkha, Algeria. Int J Syst Evol Microbiol 56, 1583-1588.

Lizama, C., Monteoliva-Sánchez, M., Suárez-García, A., RossellóMora, R., Aguilera, M., Campos, V. \& Ramos-Cormenzana, A. (2002). Halorubrum tebenquichense sp. nov., a novel halophilic archaeon isolated from the Atacama Saltern, Chile. Int J Syst Evol Microbiol 52, 149-155.

Lopez-Garcia, P., Moreira, D., Lopez-Lopez, A. \& Rodríguez-Valera, F. (2001). A novel haloarchaeal-related lineage is widely distributed in deep oceanic regions. Environ Microbiol 3, 72-78. 
Ludwig, W., Strunk, O., Westram, R., Richter, L., Meier, H., Yadhukumar, Buchner, A., Lai, T., Steppi, S. \& other authors (2004). ARB: a software environment for sequence data. Nucleic Acids Res 32, 1363-1371.

Marmur, J. (1961). A procedure for the isolation of deoxyribonucleic acid from microorganisms. J Mol Biol 3, 208-218.

Marmur, J. \& Doty, P. (1962). Determination of the base composition of deoxyribonucleic acid from its thermal denaturation temperature. J Mol Biol 5, 109-118.

McGenity, T. J. \& Grant, W. D. (1995). Transfer of Halobacterium saccharovorum, Halobacterium sodomense, Halobacterium trapanicum NRC 34021 and Halobacterium lacusprofundi to the genus Halorubrum gen. nov., as Halorubrum saccharovorum comb nov., Halorubrum sodomense comb nov., Halorubrum trapanicum comb. nov., and Halorubrum lacusprofundi comb. nov. Syst Appl Microbiol 18, 237-243.

McGenity, T. J. \& Grant, W. D. (2001). Genus VII. Halorubrum. In Bergey's Manual of Systematic Bacteriology, 2nd edn, vol. 1, pp. 320324. Edited by D. R. Boone, R. W. Castenholz \& G. M. Garrity. New York: Springer.

Oren, A. (1983). Halorubrum sodomense sp. nov., a Dead Sea halobacterium with an extremely high magnesium requirement. Int J Syst Bacteriol 47, 233-238.

Oren, A. \& Ventosa, A. (1996). A proposal for the transfer of Halorubrobacterium distributum and Halorubrobacterium coriense to the genus Halorubrum as Halorubrum distributum comb. nov. and Halorubrum coriense comb. nov., respectively. Int J Syst Bacteriol 46, 1180.

Oren, A., Ventosa, A. \& Grant, W. D. (1997). Proposed minimal standards for description of new taxa in the order Halobacteriales. Int J Syst Bacteriol 47, 233-238.

Oren, A., Vreeland, R. H. \& Ventosa, A. (2007). International Committee on Systematics of Prokaryotes Subcommittee on the taxonomy of Halobacteriaceae and Subcommittee on the taxonomy of Halomonadaceae. Minutes of the joint open meeting, 3 September 2007, Colchester, UK. Int J Syst Evol Microbiol 57, 2975-2978.

Owen, R. J. \& Hill, L. R. (1979). The estimation of base compositions, base pairing and genome size of bacterial deoxyribonucleic acids. In Identification Methods for Microbiologists, 2nd edn, pp. 217-296. Edited by F. A. Skinner \& D. W. Lovelock. London: Academic Press.
Pagaling, E., Haigh, R. D., Grant, W. D., Cowan, D. A., Jones, B. E., Ma, Y., Ventosa, A. \& Heaphy, S. (2007). Sequence analysis of an archaeal virus isolated from a hypersaline lake in Inner Mongolia, China. BMC Genomics 8, 410.

Petter, H. F. M. (1931). On bacteria of salted fish. Proc K Ned Akad Wet Amsterdam 34, 1417-1423.

Rodriguez-Valera, F., Ruiz-Berraquero, F. \& Ramos-Cormenzana, A. (1981). Characteristics of the heterotrophic bacterial populations in hypersaline environments of different salt concentrations. Microb Ecol 7, 235-243.

Saitou, N. \& Nei, M. (1987). The neighbor-joining method: a new method for reconstructing phylogenetic trees. Mol Biol Evol 4, 406-425.

Stackebrandt, E. \& Goebel, B. M. (1994). Taxonomic note: a place for DNA-DNA reassociation and $16 \mathrm{~S}$ rRNA sequence analysis in the present species definition in bacteriology. Int J Syst Bacteriol 44, 846-849.

Tomlinson, G. A. \& Hochstein, L. I. (1976). Halobacterium saccharovorum sp. nov., a carbohydrate-metabolizing, extremely halophilic bacterium. Can J Microbiol 22, 587-591.

Torreblanca, M., Rodriguez-Valera, F., Juez, G., Ventosa, A., Kamekura, M. \& Kates, M. (1986). Classification of non-alkaliphilic halobacteria based on numerical taxonomy and polar lipid composition, and description of Haloarcula gen. nov. and Haloferax gen. nov. Syst Appl Microbiol 8, 89-99.

Ventosa, A. (2006). Unusual micro-organisms from unusual habitats: hypersaline environments. In Prokaryotic Diversity: Mechanisms and Significance (Society for General Microbiology Symposium no. 66), pp. 223-253. Edited by N. A. Logan, H. M. Lappin-Scott \& P. C. F. Oyston. Cambridge: Cambridge University Press.

Ventosa, A., Gutiérrez, M. C., Kamekura, M., Zvyagintseva, I. S. \& Oren, A. (2004). Taxonomic study of Halorubrum distributum and proposal of Halorubrum terrestre sp. nov. Int J Syst Evol Microbiol 54, 389-392.

Xu, X.-W., Wu, Y.-H., Zhang, H.-b. \& Wu, M. (2007). Halorubrum arcis sp. nov., an extremely halophilic archaeon isolated from a saline lake on the Qinghai-Tibet Plateau, China. Int J Syst Evol Microbiol 57, 1069-1072. 